\title{
Kirjallisuutta
}

\section{Haasteen ymmärtäminen}

Kusch, Martin: Ymmärtämisen haaste. Kustannusosakeyhtiö Pohjoinen, Jyväskylä 1986, $256 \mathrm{~s}$.

Hermeneutiikka on tekemisissä ymmärtämisen ja tulkitsemisen kanssa. Tämä ei kuitenkaan ole hermeneutiikan yksinoikeus ja siksi sen määrittely on vaikeaa. Rajat erityistieteisiin, fenomenologiaan ja analyyttisen filosofian perinteeseen ovat liukuvat. Historiallisesti hermeneutiikan kehitystä on jaoteltu a) oikein-ymmärtämisen-sääntöjen hermeneutiikkaan (esiheideggerilainen vaihe), b) eksistentiaali-hermeneutiikkaan (Heidegger, Gadamer) ja c) kriittisen tai dialektisen hermeneutiikan (Apel, Habermas). Tämäkin jaottelu on kuitenkin ongemallinen. Siksi Martin Kuschin pyrkimys esittää nykyaikaisen hermeneutiikan historia "huipulta huipulle" Schleiermacherista Hebermasiin on tehtävänä vaikea ja vaativa. Myös lukija haastetaan ei vain lukemaan oppikirjaksi tarkoitettua kirjaa, vaan myös ymmärtämään ja sitä kautta tulkitsemaan haastetta. Kusch onnistuu haasteessa: teos on vaativa, mutta ei ole huolelliselle lukijalle mahdoton: teos on selkeä, mutta ei ole yksinkertaistetun tuntuinen: teos on tiivis, mutta se ei tukehdu asioiden runsauteen: teos on omintakeinen, mutta ei ole subjektiivisen mielivallan tulos. Teos ei ole ehkä hauska, mutta sen antama älyllinen nautinto on poikkeuksellinen suomalaisessa filosofisessa kirjallisuudessa.

Kirja etenee historiallisesti. Lyhyen hermeneutiikan käsitteen ja varhaisen hermeneutiikan esittelyn jälkeen Kusch käsittelee seuraavia hermeneutikkoja: Schleiermacher, Dilthey, Heidegger, Gadamer, Habermas. Kahden viimemainitun käsittelyn väliin on sijoitettu kappaleet, joissa tarkastellaan hermeneutiikan, psykoanalyysin, ideologiakritiikin ja materialismin suhdetta (Ricoeur, Lorenzer, Habermas, Sandkühler) sekä analyyttistä hermeneutiikkaa Winch, Apel, 'Habermas, Kannisto, von Wright, Itkonen, Tuomela, Niiniluoto, Apel).

Modernin hermeneutiikan ensimmäinen klassikko Friedrich Schleiermacher (1768-1834) on jäänyt filosofisessa kirjallisuudessa usein Georg Friedrich Wilhelm Hegelin (1770-1831) varjoon. Schleiermacher oli Hegelin kiistakumppani ja myöhempi filosofian historia on usein nojautunut Hegelin, etenkin uskonnonfilosofi- seen, Schleyermacher-kritiikkiin. Myöhemmin Wilhelm Diltheyn (1833-1911) antama kuva Schleiermacherista oli yksipuolinen. Kusch pyrkii osoittamaan, että on tarpeen uudelleenarvioida Schleiermacherin panosta hermeneutiikan historiassa ja osoittaa, että hänellä on enemmän annettavaa kuin pelkkä "eläytymisen teoria". Schleiermacherin esittelyn lisäksi Kusch perustelee hänen ajankohtaisuutensa yhdistämällä hänen ajatuksiaan Ricoaurin, Sartren ja Davidsonin käsityksiin.

Jakso Heideggerista on edellä mainitun lisäksi uutta suomalaisessa keskustelussa (tätä täydentää Synteesi-lehden teemanumero 2-3/ 1986). Dilthey, Gadamer ja etenkin Habermas on ollut esillä käydyissä keskusteluissa (osittain tosin enemmän yhteiskuntatieteiden metodologiasta ja filosofisesta perustasta käydyssä keskustelussa kuin "varsinaisessa" filosofisessa keskustelussa). Heideggerin filosofian esittäminen suomeksi on sitäkin oleellisempaa, koska suomalaisille Heideggeriin liittyy moninkertaisia ymmärtämisen ongelmia: Heideggerin saksankieli on erityisen vaativaa runollisuudessaan ja jo saksaksikin vaikea teksti ei tahdo luontevasti kääntyä 
omalle kielellemme. Lisäksi Heideggerin henkilöön liittyy historiallisia rasitteita, jotka eivät helpota hänen filosofiansa tulkintaa. Kusch liikkuu kuitenkin tarkastelussaan tekstin lähellä ja tyytyy kritisoimaan häntä kielifilosofian lähtökohdista ja kielen sivuuttamisesta "olemisen" analyysissä. Näin voidaan välttyä arvioimasta Heideggerin filosofian ei-välittömästi filosofisia ulottuvuuksia (yhteiskunnallisuus, poliittisuus, ideologisuus). Tätä ei tietysti voi vaatia, vaikka sen mukaan ottaminen olisi jossakin muodossa tarpeen (vaikkakaan ei muodissa).

Tärkein kappale teoksessa on kuitenkin analyyttistä hermeneutiikkaa käsittelevä. Siinä yhdistyy Kuschin omat pyrkimykset yhdistää hermeneutiikan traditiota analyytti- sen kielifilosofian perinteeseen. Sofistikoimalla kielifilosofian välinein hermeneutikkojen usein hämärää tekstiä voidaan olettaa päästävän eron monista epäselvyyksistä ja toisaalta kielifilosofia voi saada uutta metodista syvyyttä. Syvennystä yhteiskuntafilosofiseen ja historialliseen suuntaan jää kuitenkin kaipaamaan.

Yhdessä Heikki Kanniston "Vuosisatamme filosofia" (1986) teoksessa julkaiseman "Ymmärtäminen, kritiikki ja hermeneutiikka" -esseen kanssa Kuschin esitys antaa hyvän mahdollisuuden opiskella analyyttisen hermeneutiikan perusteita. Esitysten tarkempi arvioiminen ei tässä yhteydessä ole mahdollista, varsinkin kun vielä on avoinna Schleiermacherin maksiimin jälkimmäinen osa:
"Tehtävä voidaan ilmaista myös siten, että puhetta on ymmärrettävä ensin yhtä hyvin ja sitten paremmin kuin sen luoja (on sen ymmärtänyt )."

Kuschin kirja haastaa ymmärtämään hermeneutiikan tavoitteita ja myös ymmärtämään ne paremmin kuin hermeneutikot ovat itse sen tehneet.

\section{Pekka Kalli}

\section{Kirjallisuus:}

Kannisto, H.: Ymmärtäminen, kritiikki ja hermeneutiikka. Teoksessa: Niiniluoto-Saarinen (toim.): Vuosisatamme filosofia, WSOY, Hki 1986

Synteesi 2-3/1986, Heidegger teemanumero 